ciele wszystkich bibliotek lubelskich, zarówno naukowych, jak i publicznych, szkolnych i pedagogicznych. Konferencja cieszyła się też dużym zainteresowaniem wśród studentów, którzy nie tylko uczestniczyli w obradach, ale również wspierali pracowników Instytutu przy organizacji konferencji. Ich zaangażowanie niewątpliwie przyczyniło się do pozytywnego od- bioru konferencji. Organizatorzy mają nadzieję, że kolejna konferencja z cyklu zaplanowana na rok 2016 będzie równie interesująca i owocna.

Renata Malesa

Instytut Informacji Naukowej i Bibliotekoznawstwa Uniwersytetu Marii Curie-Skłodowskiej w Lublinie
W dniach 23-24 października 2014 r. odbyła się na Uniwersytecie Mikołaja Kopernika w Toruniu czwarta edycja Ogólnopolskiej Konferencji Naukowej „Niewygodne dla władzy. Ograniczanie wolności słowa na ziemiach polskich od wieku XIX do czasów współczesnych". Wydarzenie ma charakter cykliczny i organizowane jest co dwa lata przez Instytut Informacji Naukowej i Bibliologii Uniwersytet Mikołaja Kopernika ${ }^{1}$ [dalej: IINiB UMK].

1 Pierwsza edycja konferencji odbyła się w 2008 r. W roli referentów uczestniczyło w niej 32 przedstawicieli nauki z 11 polskich ośrodków naukowych. Łącznie w czasie obrad zaprezentowano 31 referatów. Podczas drugiej konferencji z omawianego cyklu, w 2010 r., w Toruniu gościło 36 badaczy, którzy wygłosili 33 referaty. Edycja trzecia w 2012 r. zaowocowała 22 referatami zaprezentowanymi przez 23 prelegentów z Torunia i 15 innych polskich miast.

\section{Niewygodne dla władzy. Ograniczanie wolności stowa na ziemiach polskich od wieku XIX do czasów wspókczesnych}

DOI: http://dx.doi.org/10.12775/TSB.2015.012

Otwarcia konferencji dokonali prorektor UMK prof. dr hab. Andrzej Sokala oraz prodziekan Wydziału Nauk Historycznych prof. dr hab. Wiesław Sieradzan, a w imieniu organizatorów głos zabrała prof. dr hab. Grażyna Gzella. W tegorocznym spotkaniu udział wzięli badacze z dziesięciu ośrodków akademickich. Najsilniej reprezentowany był uniwersytet toruński oraz Uniwersytet Pedagogiczny z Krakowa. Ponadto w Toruniu gościli pracownicy naukowi z Lublina, Poznania, Warszawy, Wrocławia, Katowic, 
Kielc, Słupska oraz Łodzi. W czasie obrad zaprezentowano 25 referatów o zróżnicowanej tematyce. Większość miała charakter interdyscyplinarny. Obejmowały ingerencje cenzorskie książek oraz na łamach prasy, również dotyczące publikacji kartograficznych, komiksów czy korespondencji.

Pierwszego dnia konferencji, w ramach obrad plenarnych, wygłoszono osiem referatów. Sesję rozpoczęło wystąpienie dr. Henryka Bałabucha z Instytutu Historii Uniwersytetu Marii Curie-Skłodowskiej w Lublinie [dalej: UMCS] zatytułowane „Pozainstytucjonalne formy cenzury XIX-wiecznej próba konceptualizacji obszaru badawczego". Referat stanowił zbiór refleksji nad pozainstytucjonalnymi formami cenzury. Kolejny referat wygłosiła prof. dr hab. G. Gzella (IINiB UMK). Omówiono $\mathrm{w}$ nim procesy prasowe redaktorów „Gazety Toruńskiej” z lat 1867-1914, począwszy od pierwszego procesu w 1872 r., aż do wybuchu I wojny światowej. Prelegentka dokonała porównania wymiaru nałożonych kar finansowych i długości pobytów członków redakcji w więzieniu. „Dozwolona krytyka dziennikarska czy występek? Redaktorzy czasopism krakowskich wobec konfiskat prasowych (1918-1939)" to temat kolejnego wystąpienia. Dr hab. Grażyna Wrona z Instytutu Informacji Naukowej i Bibliotekoznawstwa Uniwersytetu Pedagogicznego w Krakowie [dalej: IINiB
UP] wskazała w nim nowe, rzadko wykorzystywane źródła do poznania mechanizmów funkcjonowania cenzury, którym były sprzeciwy, apelacje i zażalenia formułowane przez redaktorów i wydawców przeciwko orzeczeniom sądowym wnoszącym o konfiskatę czasopisma. Natomiast dr hab. Małgorzata Korczyńska-Derkacz (Instytut Informacji Naukowej i Bibliotekoznawstwa Uniwersytetu Wrocławskiego) przedstawiła wytyczne Komitetu Centralnego Polskiej Partii Robotniczej dotyczące działalności dwóch spółdzielni wydawniczych, „Czytelnika” i „Książki”, wskazując, jak silnie partia wpływała na ich aktywność na rynku książki.

Po krótkiej przerwie z referatem na temat kartografii wojskowej pt. „Cenzura wojskowa wobec treści map przeznaczonych dla społeczeństwa okresu PRL" wystąpiła dr hab. Beata Konopska (Instytut Geodezji i Kartografii w Warszawie). Autorka w bardzo obrazowy sposób zaprezentowała metody fałszowania map w okresie PRL. Następny referat dotyczył perlustracji listów, dr hab. Piotr Nowak (Instytut Językoznawstwa Uniwersytetu im. Adama Mickiewicza w Poznaniu) omówił w nim nietypowe metody operacyjne stosowane podczas cenzury korespondencji. Następnie dr hab. Katarzyna Tałuć (Instytut Bibliotekoznawstwa i Informacji Naukowej Uniwersytetu Śląskiego w Katowicach), w referacie „Niezależna polska prasa 
młodzieżowa lat 80. XX w. - czasopisma Międzyszkolnego Komitetu Oporu", zaprezentowała nielegalne przedsięwzięcia wydawnicze podejmowane przez młodzież w latach 80. jako formę wyrazu swojego sprzeciwu nie tylko wobec władzy, ale także buntu wobec pokolenia rodziców. Kolejna prelegentka - dr Kamila Kamińska (Instytut Dziennikarstwa Uniwersytetu Warszawskiego) - wystąpiła z referatem poświęconym ostatnim miesiącom działania cenzury w PRL (1989-1990), w którym zaprezentowała zakres ówczesnych ingerencji, m.in. pod względem ilościowym. Pierwszą część obrad zakończyła ożywiona dyskusja. Najwięcej zainteresowania wykazano dwóm tematom: perlustracji listów i fałszowaniu map.

Po przerwie rozpoczęły się obrady w dwóch sekcjach. Pierwszą otworzył prof. dr hab. Jacek Gzella (IINiB UMK) wystąpieniem pt. „Władysława Studnickiego kłopoty z cenzurą w 1907 r." Badacz z Torunia szeroko omówił kłopoty z cenzurą wydawcy dwutygodnika „Naród a Państwo”. Natomiast mgr Marcin Żynda, także pracownik IINiB UMK, prezentując problemy $\mathrm{z}$ wolnością słowa $\mathrm{w}$ dwudziestoleciu międzywojennym, wskazał na skonfiskowany „List Gazety Grudziądzkiej” z 1933 r. jako na interesujący przykład próby poinformowania czytelników o funkcjonowaniu aparatu cenzury. Kolejne wystąpienie, pozostające z po- przednim w związku chronologicznym, dotyczyło wydawnictw satyrycznych Torunia i Grudziądza tego samego okresu. Referat na ten temat wygłosił mgr Piotr Rudera (IINiB UMK). Ciekawy przypadek cenzury nakreśliła dr hab. Agnieszka Cieślikowa (Instytut Historii PAN w Warszawie) w prezentacji zatytułowanej „«Kurier Wołyński» w starciu z wojewodą Józewskim 1937-1938". Referentka obrazowo przedstawiła wojewodę Henryka Józewskiego, właściciela tygodnika „Wołyń”, wykorzystującego osobiste wpływy do walki z opozycyjnym pismem „Kurier Wołyński". Natomiast cyklowi felietonów satyrycznych „Z notatnika cenzora obozowego" swoje wystąpienie poświęcił prof. dr hab. Krzysztof Woźniakowski (IINiB UP). Była to udana próba analizy felietonów satyrycznych publikowanych od 22 VIII 1943 do 30 I 1944 r., ukazujących się w budapeszteńskich „Wieściach Polskich”. Jak wskazał K. Woźniakowski, autorstwo cyklu nie jest pewne, przypuszcza się jedynie, że tworzył go satyryk Jan Kruszewski.

Obrady w pierwszej sekcji zakończyła zaplanowana w programie dyskusja. Była to ożywiona debata o konfiskatach nakładów oraz ich różnicach w przypadku postępowania administracyjnego i karnego.

W drugiej sekcji referat wygłosiła dr Marta Pękalska z Zakładu Narodowego im. Ossolińskich we Wrocławiu 
pt. „«Wstępy muszą być nowe» - spory Wydawnictwa Ossolineum i cenzury o pierwsze powojenne edycje dawnych tomów serii „Biblioteka Narodowa”. Autorka zestawiła i porównała teksty wstępów do wybranych pozycji serii, ich edycji przed- i powojennych. Kolejne dwa wystąpienia poświęcone zostały ograniczeniom, jakim podlegały wydawnictwa naukowe w latach 50 . XX w. O procesie wydawniczym źródeł historycznych opowiadał dr hab. Robert Degen (Instytut Historii i Archiwistyki UMK [dalej: IHiA UMK]), który próbował odpowiedzieć na pytanie, co mogło blokować i spowalniać wydawanie źródeł historycznych w omawianym okresie. Natomiast dr Dorota Degen (IINiB UMK) omówiła problem wydawnictw zaniechanych jako jeden z elementów ówczesnej polityki wydawniczej. Autorka starała się wskazać straty, jakie dla nauki tamtego okresu wynikały z „zaniechania” wydania określonych tytułów. Tematem następnego referatu była „Cenzura wobec krakowskich gazet codziennych lat 60. XX w. (na przykładzie „Echa Krakowa")". Dr Adam Ruta (IINiB UP) wykazywał w nim, że działania ówczesnej cenzury nosiły znamiona paranoi, gdyż ingerowano nie tylko w artykuły, ale także w wywiady, recenzje czy ogłoszenia drobne. Ostatni referat pierwszego dnia należał do dr hab. Jolanty Chwastyk-Kowalczyk (Inst. Bibliotekoznawstwa i Dziennikarstwa Uniwersytetu
Jana Kochanowskiego w Kielcach [dalej: IBiD UJK]) i dotyczył problemów polskiej emigracji poddanych cenzurze w prasie krajowej i na obczyźnie. Blok pięciu wystąpień zakończyła dyskusja. Uczestnicy obrad interesowali się szczególnie ograniczeniami, jakim podlegały książki naukowe w połowie XX w. Omówione zostały ówczesne realia, $w$ tym także niedobory materiałowe $w$ dostępie do poligrafii i rozpowszechnianiu.

Drugi dzień konferencji - 24 października - rozpoczęło wystąpienie dr Marleny Jabłońskiej (IHiA UMK) zatytułowane „«A akta zniszczyć». Brakowanie akt SB jako ograniczenie współczesnych możliwości badawczych". Autorka wskazała w nim proces niszczenia akt przez służby państwowe i jego wpływ na dzisiejsze badania historyczne, które mogą być z tego powodu niekompletne lub częściowo zafałszowane. Zdaniem Jabłońskiej zniszczono około $50 \%$ materiałów, choć są miasta, gdzie ten odsetek sięga 90\%. Kolejny referat należał do dr. Ireneusza Bienieckiego (Instytut Bezpieczeństwa Akademii Pomorskiej w Słupsku) i dotyczył działalności kulturalno-oświatowej i jej wpływu na kształtowanie poglądów żołnierzy zasadniczej służby wojskowej jednostek ochraniających granice PRL w latach 1965-1991. Dokonano w nim oceny tejże działalności i jej wpływu na kształtowanie postaw i poglądów żołnierzy. Z kolei dr Bar- 
bara Centek (IINiB UMK), w swoim wystąpieniu zatytułowanym „Źródła do dziejów «Spotkań» (1977-1988) w zasobach IPN", wskazała na zasoby tej instytucji dotyczące działaczy środowiska „Spotkań”. Omówiła również metody, jakimi posługiwała się Służba Bezpieczeństwa w rozpracowywaniu opozycji i w jakim stopniu były one skuteczne.

Zupełnie inne obszary badań zainteresowały dwie łódzkie badaczki dr Małgorzatę Rzadkowolską oraz dr Agatę Walczak-Niewiadomską (Katedra Bibliotekoznawstwa i Informacji Naukowej Uniwersytetu Łódzkiego). Przedmiotem ich rozważań stał się dobór haseł osobowych w kolejnym suplemencie do Słownika pracowników ksiq̨żki polskiej dotyczących osób angażujących się w drugi obieg wydawniczy. Natomiast dr Grzegorz Nieć (IINiB UP) i mgr Paweł Podniesiński (Instytut Informacji Naukowej i Studiów Bibliologicznych Uniwersytetu Warszawskiego) zaprezentowali druki zakazane i bezdebitowe jako atrakcje bibliofilskie na polskich aukcjach antykwarycznych ostatnich dwudziestu lat. Przedstawili oni przykłady publikacji, które zostały wydane wbrew obowiązującym ówcześnie przepisom i które mimo to były dostępne na aukcjach. Wystąpienie Adama Górskiego (IBiD UJK) dotyczyło już czasów nam współczesnych i objęło zagadnienie cenzury prewencyjnej na tle obecnej regulacji prawnej. A. Górski zawarł w nim odpowiedź na pytanie: Czy obecnie w naszym państwie istnieje jakaś forma cenzury? I jakie konsekwencje prawne mogą wynikać z jej łamania? Ostatnia prelekcja, kończąca całą konferencję, należała do dr. Tomasza Marciniaka. Przedstawił on przykłady „igrania” z cenzurą przez autorów prac komiksowych. Komiksy często nie były traktowane przez władze poważnie, dlatego nie podlegały tak ostrej kontroli, jak pozostałe typy publikacji. Temat ten okazał się jednym z tych, które przywoływano podczas dyskusji najczęściej. Ponadto ciekawość prelegentów wzbudziły też aspekty prawne przywołane w przedostatnim wystąpieniu.

Konferencję zakończyło wystąpienie prof. dr hab. G. Gzelli, która w imieniu organizatorów podziękowała przybyłym gościom, zaprosiła do publikowania w planowanym, kolejnym tomie studiów poświęconym cenzurze oraz zapowiedziała starania $\mathrm{w}$ zakresie organizacji kolejnej - już piątej - toruńskiej konferencji poświęconej ograniczeniom wolności słowa. Ściśle merytorycznego podsumowania obrad podjęła się natomiast dr hab. G. Wrona, która wskazała najważniejsze obszary badań i podejmowane podczas obrad tematy szczegółowe oraz wnioski płynące $\mathrm{z}$ dyskusji. Potwierdziła również potrzebę kolejnych spotkań, wskazując wątki, które zostały przez badaczy „otwarte” i wymagają dalszych ustaleń. 
Wydaje się więc, że Instytut Informacji Naukowej i Bibliologii UMK za dwa lata ponownie będzie miejscem spotkania wszystkich badaczy zainteresowanych zagadnieniami szeroko pojętej cenzury.
Magdalena Ostrowska

uczestniczka studiów doktoranckich z zakresu bibliologii, prowadzonych na Wydziale Nauk Historycznych Uniwersytetu Mikołaja Kopernika w Toruniu
$J^{\omega}$ uż po raz piąty odbyła się Ogólnopolska Konferencja Naukowa „Zarządzanie informacją w nauce". Obrady odbyły się 27-28 listopada $2014 \mathrm{r}$. w Katowicach. Otwarcia imprezy dokonali reprezentanci Rady Naukowej: dr hab. Diana Pietruch-Reizes (Uniwersytet Jagielloński, dalej: UJ) oraz prof. dr hab. Wiesław Babik (UJ). Zwrócili uwagę na wieloletnią współpracę Zakładu Bibliografii i Informacji Naukowej Instytutu Bibliotekoznawstwa i Informacji Naukowej Uniwersytetu Śląskiego i Zakładu Zarządzania Informacją Instytutu Informacji Naukowej i Bibliotekoznawstwa UJ w zakresie organizowania cyklicznej konferencji naukowej, która obchodziła w tym roku mały, dziesiąty jubileusz¹. Ponadto prof. W. Babik przypomniał rok 2000, kiedy to opublikował, najprawdopodobniej pierwszy artykuł w Polsce, poruszający tematykę zarządzania

1 D. Pietruch-Reizes, Nauka jako system informacyjny. Tytułem wstępu, [w:] Zarzadzanie informacja $w$ nauce, pod red. D. Pietruch-Reizes, Katowice 2008, s. 9-13.

\section{0 zarządzaniu informacia w nauce po raz piq̨y}

DOI: http://dx.doi.org/10.12775/TSB.2015.013

informacją. Profesor podzielił się refleksją, iż nie myślał wtedy, że termin zarządzanie informacją zdobędzie taką popularność w środowisku, jaką ma dzisiaj ${ }^{2}$.

Sesję plenarną poprowadził i rozpoczął swoim wystąpieniem prof. dr hab. W. Babik (UJ). Referent postawił tezę: „organizacja wiedzy jest najistotniejszym elementem procesu zarządzania informacją w nauce". Przedstawił różne definicje organizacji wiedzy oraz wymienił sposoby tworzenia klasyfikacji wiedzy. Wystąpienie zakończyła

${ }^{2}$ W. Babik, Dostęp polskich bibliotek do światowych źródeł informacji. „Biuletyn EBIB" [online] 2000, nr 2 [dostęp 30 czerwca 2015]. Dostępny w World Wide Web: http://www.oss.wroc.pl/biuletyn/ ebib-sp2/babik.html. 